\title{
NUTRIENTS BALANCES IN BEEF CATTLE PRODUCTION SYSTEMS AND THEIR IMPLICATIONS FOR THE ENVIRONMENT
}

\section{Balances de nutrientes en sistemas de producción de carne del sur de chile y sus implicancias para el medioambiente}

\author{
M. Alfaro ${ }^{1}$, F. S. Salazar ${ }^{1}$; O. Oenema ${ }^{2}$; S. Iraira ${ }^{1}$; N. Teuber ${ }^{1}$; L. Ramirez ${ }^{1}$ and \\ D. Villarroel ${ }^{1}$ \\ ${ }^{1}$ National Institute for Agricultural Research (INIA), Remehue Research Centre. P.O. Box \\ 24-O, Osorno, Chile. Corresponding author: malfaro@inia.cl \\ ${ }^{2}$ Wageningen University and Research Center, ALTERRA. PO Box 47, NL-6700, \\ Wageningen, The Netherlands.
}

\begin{abstract}
The main inputs and outputs of nitrogen $(\mathrm{N})$ and phosphorus $(\mathrm{P})$ in soils and swards under typical Southern Chilean conditions were determined between 2004-2005 and 2006-2007 to establish soil and field gate $\mathrm{N}$ and $\mathrm{P}$ balances under different immediate stocking rates (63 and 191 anim ha ${ }^{-1} \mathrm{~d}^{-1}$ ) and field slope treatments (4 and 12\%). Treatments received 67.5 and $40 \mathrm{~kg} \mathrm{~N}$ and $\mathrm{P} \mathrm{ha}^{-1} \mathrm{yr}^{-1}$ as inorganic fertilizer. The main $\mathrm{N}$ and $\mathrm{P}$ input to the soil balances was $\mathrm{N}$ mineralization (304 $\mathrm{kg} \mathrm{ha}^{-1} \mathrm{yr}^{-1}$ ) and inorganic fertilizer (62 and $69 \%$ for $\mathrm{N}$ and $\mathrm{P}$, respectively). The main output for all treatments was plant uptake (95\% and $100 \%$ on average for $\mathrm{N}$ and $\mathrm{P}$, respectively). The $\mathrm{N}$ and $\mathrm{P}$ apparent use efficiency was high (>95\%). The main $\mathrm{N}$ and $\mathrm{P}$ input to field gate balances was inorganic fertiliser $(>95 \%)$, while animal production had a minor effect on $\mathrm{N}$ and $\mathrm{P}$ export. The soil balances ranged from -303 up to +58 and from -3 up to $+20 \mathrm{~kg}$ of $\mathrm{N}$ and $\mathrm{P} \mathrm{ha}^{-1} \mathrm{yr}^{-1}$. Field $\mathrm{N}$ and $\mathrm{P}$ gate budgets ranged between -309 up to +58 and from -8 up to $+20 \mathrm{~kg}$ of $\mathrm{N}$ and $\mathrm{P} \mathrm{ha}^{-1} \mathrm{yr}^{-1}$, respectively, indicating a potential soil degradation in areas with low nutrient inputs in inorganic fertiliser and an overaccumulation in areas with low dry matter production of the grassland, which in turn can lead to environmental constrains. This should be especially considered for dairy systems, which are more intensively managed.
\end{abstract}

Key words: stocking rate, field slope, grazing, nutrient budget.

\section{RESUMEN}

Las principales entradas y salidas de nitrógeno $(\mathrm{N})$ y fósforo $(\mathrm{P})$ en un suelo y pradera típica de las condiciones del sur de Chile fueron determinadas en 2004/05 y 2006/07 para establecer balances de suelo y puerta bajo diferentes cargas animales (63 and $191 \mathrm{anim}$ $\mathrm{ha}^{-1} \mathrm{~d}^{-1}$ ) y pendiente topográfica (4 y 12\%). Los tratamientos recibieron 67,5 y $40 \mathrm{~kg} \mathrm{~N}$ y $\mathrm{P}_{\text {ha }}{ }^{-1}$ año $^{-1}$ como fertilizante inorgánico. Las principales entradas de $\mathrm{N}$ y $\mathrm{P}$ al suelo fueron la mineralización de $\mathrm{N}$ (304 $\mathrm{kg} \mathrm{ha}^{-1}$ año $^{-1}$ ) y la fertilización inorgánica (62 y $69 \%$ para N y $\mathrm{P}$, respectivamente). Las principales salidas para todos los tratamientos fue la extracción de las plantas (95\% y $100 \%$ en promedio para $\mathrm{N}$ y P, respectivamente). La eficiencia de uso de $\mathrm{N}$ y $\mathrm{P}$ fue alta (>95\%). El principal ingreso de $\mathrm{N}$ y P al balance de puerta fue el 
fertilizante inorgánico ( $>95 \%)$, mientras que la producción animal tuvo un efecto despreciable sobre la exportación de $\mathrm{N}$ y $\mathrm{P}$. Los balances de suelo variaron entre -303 y +58 , y desde -3 a $+20 \mathrm{~kg}$ de $\mathrm{N}$ y $\mathrm{P} \mathrm{ha}^{-1}$ año $^{-1}$. Los balances de puerta variaron entre -309 y +58 , y entre -8 y $+20 \mathrm{~kg}_{\text {de }} \mathrm{N}$ y $\mathrm{P} \mathrm{ha}^{-1} \mathrm{año}^{-1}$, respectivamente, indicando un potencial de degradación de suelo en áreas con bajo ingreso de nutrientes en fertilizantes inorgánicos y una sobreacumulación en áreas con bajo nivel de producción de materia seca, lo que puede resultar en restricciones medioambientales. Esto debería considerarse especialmente en sistemas de producción de leche, que son más intensivamente manejados.

Palabras claves: carga animal, pendiente topográfica, pastoreo, balances de nutrientes.

\section{INTRODUCTION}

The Lake Region of southern Chile has suitable climatic conditions and soil types for cattle production. Consequently, 56\% of the national cattle herd is concentrated in this maritime temperate climatic region, grazed on natural and improved pastures. These cattle produce $70 \%$ of the country's milk and 50\% of the meat (INE, 2007). In addition, $80 \%$ of Chile's dairy farmers are located in this region and they own $67 \%$ of the land dedicated to dairy production used nationally (Anrique, 1999).

Livestock production use nitrogen $(\mathrm{N})$ and phosphorus $(\mathrm{P})$ as inorganic fertilizer, being these elements the main cost of fertilizer application. In grasslands, Nfertilization range between $0-200 \mathrm{~kg} \mathrm{~N}$ $\mathrm{ha}^{-1} \mathrm{yr}^{-1}$ and $\mathrm{P}$-fertilization range between 35-90 kg $\mathrm{P} \mathrm{ha} \mathrm{yr}^{-1}$, with possible implications for $\mathrm{N}$ and $\mathrm{P}$ positive surpluses in these livestock systems. Also, and $\mathrm{N}$ and $\mathrm{P}$ inputs in animal feed has increased over the last ten years in the area, because of the use of greater stocking rates (Alfaro and Salazar, 2005), which in turn, demands a greater nutrient input per area unit. Despite this, Chilean livestock systems can be considered as extensive if compared with European, New Zelander or Northeamerican productive systems, where inputs in fertilizers and animal feed overcome inputs compared to our conditions.

Nutrient balances have been widely used as tools for predicting the potential environmental impact of livestock systems (i.e. Ledgard et al., 1999) and their contribution to farming and policy decisions has increased in the past few years. Nevertheless, this methodology has restrictions as they can not be used alone as safe guidelines for farmers or scientists, because of the need to account for individual items (inputs, outputs), in both absolute and relative terms (Van Noordwijk, 1999). In European countries $\mathrm{N}$ and $\mathrm{P}$ balances usually show surpluses of these nutrients, with potential negative environmental impacts (i.e. Jarvis, 1993; Haygarth et al., 1998).

In Chile, there is little information on $\mathrm{N}$ soil and farm budgets (Dumont and Alfaro, 1998; Nuñez et al., 2008), with no published data for $\mathrm{N}$ budgets for closed grazed systems or $\mathrm{P}$ budgets in grazed areas. The objective of our study was to establish $\mathrm{N}$ and $\mathrm{P}$ soil and field gate balances in grassland systems of Southern Chile, with different immediate stocking rates and different field slopes. The results of this study will help to validate this tool for Chilean livestock systems and will contribute to focus the research on environmental aspects related to livestock production under local conditions.

\section{MATERIALS AND METHODS}

\section{Experimental site}

A field experiment at INIA Remehue (40³5' S, $73^{\circ} 12^{\prime}$ W) was used between 2004 and 2006 to establish soil and gate balances for $\mathrm{N}$ and $\mathrm{P}$ in beef cattle grazing 
Table 1: Experimental treatments used in the present experiment.

Cuadro 1: Tratamientos experimentales usados en el presente experimento.

\begin{tabular}{|l|c|c|c|}
\hline Treatment/characteristic & 1 & 2 & 3 \\
\hline Field slope & $4 \%$ & $4 \%$ & $12 \%$ \\
\hline Immediate stocking rate $\left(\mathrm{anim} \mathrm{ha}^{-1} \mathrm{~d}^{-1}\right)$ & 63 & 191 & 63 \\
\hline Nutrient application $\left(\mathrm{kg} \mathrm{ha}^{-1} \mathrm{yr}^{-1}\right)$ & & & \\
\hline $\mathrm{N}$ (urea, sodium nitrate) & 67.5 & 67.5 & 67.5 \\
\hline P (triple superphosphate) & 40 & 40 & 40 \\
\hline Grass management & Grazed & Grazed & Grazed \\
\hline Suplementary feed & Hay & Hay & Hay \\
\hline
\end{tabular}

systems. Soil at the site is an Andisol from the Osorno soil series (Typic Hapludands; CIREN, 2003), with 6\% slope, $>1$ m depth, $18 \%$ organic matter content, high Olsen $\mathrm{P}$ and low aluminium saturation index (Table 1). This index describes the relationship between $\mathrm{Al}$ and other cations in the soil solution $(\mathrm{Ca}+\mathrm{Mg}+\mathrm{K}+\mathrm{Na})$. According to a weather station located within $1 \mathrm{~km}$ distance, the mean annual precipitation for the area is $1,278 \mathrm{~mm}$ after $31 \mathrm{yr}$ records.

\section{Treatments}

Two immediate stocking rates of 63 and 191 steers $^{-1}$ day $^{-1}$ were tested on a $4 \%$ soil slope paddock and the 63 steers ha $^{-1}$ day $^{-1}$ treatment was also tested on a $12 \%$ soil slope padock (Table 1). All systems were managed as closed beef cattle production systems ( $c a .2$ ha each) grazed by Holstein-Friesian steers (3.5 steers $\mathrm{ha}^{-1}$ ) with an initial live weight of $212 \pm 9.9 \mathrm{~kg}$, $173 \pm 23.0 \mathrm{~kg}$ and $248 \pm 12.0 \mathrm{~kg}$ for 2004 , 2005 and 2006, respectively. The grazing periods varied between years and the average number of grazing days was 250. During winter time (60 days) animals received hay as supplementary feed.
Paddocks were divided into 54 strips and animals were managed under rotational grazing on a permanent pasture 20 years old that had always been used for grazing with beef cattle, with one new strip every third day for the low immediate stocking rate and one new strip each day for the high immediate stocking rate treatments. The main plant species in the pasture were Lolium perenne, Dactylis glomerata and Holcus lanatus. The numbers of grazings during the drainage period were six, 10 and nine for 2004, 2005 and 2006, respectively.

The treatments were fertilized in autumn 2004 (April), applying $45 \mathrm{~kg} \mathrm{~N}^{-1}$ (urea fertilizer, $46 \% \mathrm{~N}$ ) and in spring (early September), with $22.5 \mathrm{~kg} \mathrm{~N}^{-1}$ (sodium nitrate, $16 \% \mathrm{~N}$ ) and $30 \mathrm{~kg} \mathrm{P} \mathrm{ha}^{-1}$ (triple superphosfate, TSP, 46\% $\mathrm{P}_{2} \mathrm{O} 5$ ). During autumn (March) 2005 and 2006 the treatments were again fertilized with $45 \mathrm{~kg}$ $\mathrm{N} \mathrm{ha}^{-1}$ (sodium nitrate). In spring (final August) 2005 and 2006 the treatments received $22.5 \mathrm{~kg} \mathrm{~N}^{-1}$ (sodium nitrate) and $30 \mathrm{~kg} \mathrm{P} \mathrm{ha}^{-1}$ (TSP). The amount and timing of fertilizer applications represented the typical management of a beef farm in the area. 


\section{Soil sampling}

Soil samples were taken randomly from all treatments following a zig zag distribution, in February each year at 0-10 and 10-20 cm depth. Sixteen cores were taken randomly on each occasion and the samples were bulked into two duplicates forOlsen $\mathrm{P}$ and other nutrients according to the methodology described by Sadsawka (1990).

Nitrogen and phosphorus losses To quantify $\mathrm{N}$ and $\mathrm{P}$ losses in surface runoff, three surface lysimeters $(5 \times 5 \mathrm{~m}, 0.5 \mathrm{~m}$ depth) were established in each closed treatment. The lysimeter is a dimanond shape plot that isolates a known area of the paddock, allowing the collection of surface runoff and subsurface runoff $(0-50 \mathrm{~cm})$ with the use of drainage pipes (Alfaro and Salazar, 2007). Lysimeters were isolated with the use of a portable electric fence to avoid contamination with urine or dung from grazing animals. Leaching was estimated as the difference between rainfall and evapotranspiration at the site, after discounting surface and subsurface runoff. Nitrogen leaching losses at $60 \mathrm{~cm}$ depth were estimated with the use of ceramic cups (nine per treatment). Leachate samples were collected fortnightly in 2004 and every 100 $\mathrm{mm}$ drainage in 2005 and 2006. Drainage for the period was calculated according to Lord and Shepherd (1993).

\section{Nitrogen and phosphorus inputs in rainfall}

Rainfall was measured with an automatic weather station placed within $1 \mathrm{~km}$ distance of the experimental site and weekly samples of rainfall were analysed for available $\mathrm{N}$ and $\mathrm{P}$, according to Robarge et al. (1983) for nitrate, Mulvaney et al. (1996) for ammonium and Clesceri et al. (1998) for P.

\section{Dry matter production (DM)}

Dry matter yield of the pasture was measured with the use of three exclusioncages $\left(1 \mathrm{~m}^{2}\right)$ which were cut at the ground level immediately after grazing. These data was compared with the residual vegetal material cut from a contiguous cage $(0.5$ $\mathrm{m}^{2}$ ), so that the sampling of the exclusion cages was consider the initial availability of green matter (entrance) and that from the contiguous cage was considered as the final availability (remainder). The net production of DM was calculated as the difference between the total availability before grazing (exclusion cage) and that considered in the remainder of each grazing (contiguous cage), based on the DM content of the harvested forage. The fresh material (initial and remainder) was weighed and $200 \mathrm{~g}$ were then oven dried at $60^{\circ} \mathrm{C}$ by 48 hours or until constant weight. A sub sample of the initial material was then grounded in a Willey mill (1 mm sieve) for later laboratory analysis of N (Kjeldahl; AOAC, 1970) and P (Sadzawka et al., 2004). Using this information and the total DM production, the total $\mathrm{N}$ and $\mathrm{P}$ plant uptake for the relevant period was calculated.

\section{Livestock production}

The animals were weighed once per month and the total $\mathrm{N}$ and $\mathrm{P}$ export in live weight was estimated according to Haynes and Williams (1993) and NRC (1996).

Nitrogen and phosphorus budgets For the soil budgets, $\mathrm{N}$ and $\mathrm{P}$ applied as fertilizer and $\mathrm{N}$ and $\mathrm{P}$ recycled from grazing, $\mathrm{N}$ and $\mathrm{P}$ deposition in rainfall, $\mathrm{N}$ generated by biological fixation (NBF), and $\mathrm{N}$ mineralization were considered as inputs. The legumes contribution was estimated according to Ledgard et al. (1999) and $\mathrm{N}$ mineralization according to Hatch et al. (1990). Nitrogen leaching, N volatilization and total $\mathrm{N}$ plant uptake were considered as outputs. Leaching was determined as described previously and ammonia volatilization according to Misselbrook et al. (2000). For the field gate budgets (i.e. inputs and outputs entering and leaving the paddocks), $\mathrm{N}$ and $\mathrm{P}$ in fertilizers and supplementary feed were considered as inputs and animal export as output. By definition, field gate balances do not consider atmospheric deposition . Balances were used to estimate the apparent $\mathrm{N}$ and 
44 Nutrients balances in beef cattle and their impact on the environment, Alfaro et al.

P use efficiency for primary (soil balances) and secondary (gate balances) production, according to .

\section{Statistical analysis}

ANOVA test was used to determine significant differences between treatments for dry matter production and $\mathrm{N}$ and $\mathrm{P}$ content of the grass. For these variables, replicated samples (three for DM and nutrients content) were considered at each sampling time. For the animal export data the effect of the year was used as replicate to increase the number of degree of freedom. Differences in soil and gate balances between treatments were calculated using the effect of the years as replicates. Genstat 7.1 was used as statistical package.

Table 2: Effect of treatments on soil parameters $(0-20 \mathrm{~cm})$; averages for autumn 2004, 2005 and 2006 ( s.e.).

Cuadro 2: Efectos de los tratamientos sobre los parámetros de suelo $(0-20 \mathrm{~cm})$; promedios para los otoños 2004, 2005 y 2006 (土 e.e.).

\begin{tabular}{|c|c|c|c|}
\hline Parameter & $\begin{array}{c}63 \text { anim ha }{ }^{-1} \mathrm{~d}^{-1}, \\
4 \% \text { slope }\end{array}$ & $\begin{array}{c}191 \text { anim ha- } \mathrm{d}^{-1}, \\
4 \% \text { slope }\end{array}$ & $\begin{array}{c}63 \text { anim ha- } \mathrm{d}^{-1}, \\
12 \% \text { slope }\end{array}$ \\
\hline \multicolumn{4}{|l|}{2004} \\
\hline Olsen $\mathrm{P}\left(\mathrm{mg} \mathrm{kg}^{-1}\right)$ & $27 \pm 44$ & $26 \pm 4.6$ & $29 \pm 4.0$ \\
\hline Water $\mathrm{pH}$ & $5.6 \pm 0.07$ & $5.4 \pm 0.17$ & $5.6 \pm 0.02$ \\
\hline Organic matter (\%) & $18 \pm 0.2$ & $19 \pm 1.6$ & $18 \pm 0.6$ \\
\hline Sulphur (mg kg-1) & $4 \pm 1.6$ & $7 \pm 0.1$ & $4 \pm 0.3$ \\
\hline $\mathrm{Al}$ saturation index (\%) & $5 \pm 2.4$ & $7 \pm 0.8$ & $5 \pm 2.1$ \\
\hline \multicolumn{4}{|l|}{2005} \\
\hline Olsen $\mathrm{P}\left(\mathrm{mg} \mathrm{kg}^{-1}\right)$ & $25 \pm 2.2$ & $27 \pm 1.2$ & $31 \pm 4.4$ \\
\hline Water $\mathrm{pH}$ & $5.7 \pm 0.02$ & $5.6 \pm 0.01$ & $5.6 \pm 0.02$ \\
\hline Organic matter (\%) & $18 \pm 0.7$ & $19 \pm 0.7$ & $18 \pm 1.7$ \\
\hline Sulphur (mg kg-1) & $3 \pm 0.8$ & $5 \pm 0.7$ & $4 \pm 2.8$ \\
\hline Al saturation index (\%) & $4 \pm 1.5$ & $5 \pm 0.3$ & $4 \pm 2.0$ \\
\hline \multicolumn{4}{|l|}{2006} \\
\hline Olsen $\mathrm{P}\left(\mathrm{mg} \mathrm{kg}^{-1}\right)$ & $21 \pm 5.4$ & $20 \pm 5.0$ & $29 \pm 4.0$ \\
\hline Water $\mathrm{pH}$ & $5.8 \pm 0.02$ & $5.8 \pm 0.02$ & $5.8 \pm 0.05$ \\
\hline Organic matter (\%) & $17 \pm 1.4$ & $17 \pm 1.8$ & $18 \pm 1.6$ \\
\hline Sulphur (mg kg-1) & $11 \pm 0.9$ & $8 \pm 1.1$ & $8 \pm 1.4$ \\
\hline $\mathrm{Al}$ saturation index (\%) & $10 \pm 3.3$ & $10 \pm 3.1$ & $5 \pm 1.9$ \\
\hline
\end{tabular}


Table 3: Gate $\mathrm{N}$ and $\mathrm{P}$ budgets $\left(\mathrm{kg} \mathrm{ha}^{-1} \mathrm{yr}^{-1}\right)$ and nutrients use efficiency (\%) for the treatments in 2004, 2005 and 2006 ( \pm s.e.).

Cuadro 3: Balances de puerta de $\mathrm{N}$ y $\mathrm{P}\left(\mathrm{kg} \mathrm{ha}^{-1} \mathrm{año}^{-1}\right)$ y eficiencia de uso de nutrientes (\%) por tratamiento en 2004, 2005 y 2006 (土e.e).

\begin{tabular}{|c|c|c|c|c|c|c|}
\hline \multirow[t]{2}{*}{ Treatment } & \multicolumn{2}{|c|}{$\begin{array}{c}63 \text { anim ha-1 } \mathrm{d}^{-1} \text {, } \\
4 \% \text { slope }\end{array}$} & \multicolumn{2}{|c|}{$\begin{array}{c}191 \text { anim ha-1 } \mathrm{d}^{-1} \\
4 \% \text { slope }\end{array}$} & \multicolumn{2}{|c|}{$\begin{array}{c}63 \text { anim ha-1 } \mathrm{d}^{-1}, \\
12 \% \text { slope }\end{array}$} \\
\hline & $\mathrm{N}$ & $P$ & N & $P$ & $\mathrm{~N}$ & $\mathrm{P}$ \\
\hline \multicolumn{7}{|l|}{2004} \\
\hline \multicolumn{7}{|l|}{ Inputs } \\
\hline $\begin{array}{l}\text { Fertilizer } \\
\text { application }\end{array}$ & 67.5 & 40.0 & 67.5 & 40.0 & 67.5 & 40.0 \\
\hline Supplementary feed & 14.3 & 1.5 & 14.9 & 1.5 & 14.6 & 1.5 \\
\hline Total inputs & 81.8 & 41.5 & 82.4 & 41.5 & 82.1 & 41.5 \\
\hline \multicolumn{7}{|l|}{ Outputs } \\
\hline Animal export & 22.7 & 4.4 & 18.4 & 3.0 & 24.2 & 4.4 \\
\hline Soil budget 2004 & $+59,1$ & +37.1 & +64.0 & +38.5 & +57.9 & +37.1 \\
\hline Efficiency (\%) & 28 & 11 & 22 & 7 & 29 & 11 \\
\hline \multicolumn{7}{|l|}{2005} \\
\hline \multicolumn{7}{|l|}{ Inputs } \\
\hline $\begin{array}{l}\text { Fertilizer } \\
\text { application }\end{array}$ & 67.5 & 40.0 & 67.5 & 40.0 & 67.5 & 40.0 \\
\hline Supplementary feed & 19.3 & 2.4 & 17.9 & 2.2 & 19.6 & 2.5 \\
\hline Total inputs & 86.8 & 42.4 & 85.4 & 42.2 & 87.1 & 42.5 \\
\hline \multicolumn{7}{|l|}{ Outputs } \\
\hline Animal export & 23.8 & 4.5 & 21.2 & 4.5 & 14.3 & 4.5 \\
\hline Soil budget 2005 & +63 & +38 & +64 & +38 & +73 & +38 \\
\hline Efficiency (\%) & 27 & 11 & 25 & 11 & 16 & 11 \\
\hline \multicolumn{7}{|l|}{2006} \\
\hline \multicolumn{7}{|l|}{ Inputs } \\
\hline $\begin{array}{l}\text { Fertilizer } \\
\text { application }\end{array}$ & 67.5 & 40.0 & 67.5 & 40.0 & 67.5 & 40.0 \\
\hline
\end{tabular}




\begin{tabular}{|c|c|c|c|c|c|c|}
\hline \multicolumn{7}{|c|}{$\begin{array}{l}\text { Continuation Table 3: } \\
\text { Continuación Cuadro } 3\end{array}$} \\
\hline \multirow[t]{2}{*}{ Treatment } & \multicolumn{2}{|c|}{$\begin{array}{c}63 \text { anim ha-1 } d^{-1}, \\
4 \% \text { slope }\end{array}$} & \multicolumn{2}{|c|}{$\begin{array}{c}191 \text { anim ha-1 } \mathrm{d}^{-1}, \\
4 \% \text { slope }\end{array}$} & \multicolumn{2}{|c|}{$\begin{array}{c}63 \text { anim ha-1 } \mathrm{d}^{-1}, \\
12 \% \text { slope }\end{array}$} \\
\hline & $\mathrm{N}$ & $P$ & $\mathrm{~N}$ & $P$ & $\mathrm{~N}$ & $P$ \\
\hline Supplementary feed & 29.7 & 3.0 & 30.1 & 3.0 & 32.2 & 3.3 \\
\hline Total inputs & 97.2 & 43.0 & 97.6 & 43.0 & 99.7 & 43.3 \\
\hline \multicolumn{7}{|l|}{ Outputs } \\
\hline Animal export & 20.6 & 4.4 & 22.4 & 4.4 & 15.8 & 4.4 \\
\hline Soil budget 2006 & +77 & +39 & +75 & +39 & +84 & +39 \\
\hline Efficiency (\%) & 21 & 10 & 23 & 10 & 16 & 10 \\
\hline \multicolumn{7}{|l|}{ Overall } \\
\hline Inputs & $89 \pm 4.5 a$ & $42 \pm 0.4 \mathrm{a}$ & $88 \pm 4.7 \mathrm{a}$ & $42 \pm 0.4 a$ & $90 \pm 5.2 \mathrm{a}$ & $42 \pm 0.5 \mathrm{a}$ \\
\hline Outputs & $23 \pm 1.0 \mathrm{a}$ & $4 \pm 0.04 a$ & $21 \pm 1.0 \mathrm{a}$ & $4 \pm 0.5 \mathrm{a}$ & $18 \pm 3.1 b$ & $4 \pm 0.04 a$ \\
\hline Soil budget & $74 \pm 5.6 a$ & $39 \pm 0.4 a$ & $74 \pm 5.3 \mathrm{a}$ & $38 \pm 0.3 \mathrm{a}$ & $80 \pm 3.4 \mathrm{a}$ & $38 \pm 0.5 \mathrm{a}$ \\
\hline Efficiency (\%) & $25 \pm 2.2$ & $11 \pm 0.3$ & $23 \pm 0.9$ & $9 \pm 1.2$ & $20 \pm 4.3$ & $11 \pm 0.3$ \\
\hline
\end{tabular}

Different letters in columns indicate significant differences between treatments over the years for $\mathrm{N}$ and $\mathrm{P}$ balances $(\mathrm{P} \leq 0.05)$

$\mathrm{N}$ and $\mathrm{P}$ efficiency: relative efficiency of use of $\mathrm{N}$ and $\mathrm{P}$ inputs in components of the system

\section{RESULTS}

\section{Rainfall}

Total rainfall in 2004 was $1,231 \mathrm{~mm}$, similar to that of an average year for the area $(1,278$ $\mathrm{mm})$. Both 2005 and 2006 had a surplus equivalent to 201 and $182 \mathrm{~mm}$ of rainfall, respectively. Average $\mathrm{N}$ and $\mathrm{P}$ deposition in rainfall for the experimental period was $5 \pm 2.6$ and $0.5 \pm 0.20 \mathrm{~kg} \mathrm{~N}$ and $\mathrm{P} \mathrm{yr}^{-1}$, respectively.

Nitrogen and phosphorus in soil No differences were found between treatments for the soil parameters, neither between years $(\mathrm{P}>0.05$; Table 2$)$. Soil had adequate nutritional status for livestock production, excepting for the sulphur content, which could be increased through fertilizer addition. Aluminium saturation index was low at the beginning of the experiment, but increased over the years in treatments with greater dry matter yield, in response to a greater cations plant uptake, as described previosly for Andisoils by Mora et al. (2006).

\section{Nitrogen and phosphorus budgets Soil}

The main $\mathrm{N}$ and $\mathrm{P}$ input to the soil budgets was $\mathrm{N}$ mineralization and inputs in fertilizer (62 and 69\% on average for $\mathrm{N}$ and $\mathrm{P}$, respectively). The main output for all treatments was plant uptake (95\% and $100 \%$ on average for $\mathrm{N}$ and $\mathrm{P}$, respectively). Total $\mathrm{N}$ leaching losses ranged from 8 up to 17 $\mathrm{kg} \mathrm{ha}^{-1} \mathrm{yr}^{-1}$, and did not vary between treatments. Nitrogen and $\mathrm{P}$ losses in runoff were neglible (Table 3 ). The $\mathrm{N}$ and $\mathrm{P}$ apparent use efficiency was high (> 95\%). 
Table 4: Soil $\mathrm{N}$ and $\mathrm{P}$ budgets $\left(\mathrm{kg} \mathrm{ha}^{-1} \mathrm{yr}^{-1}\right)$ and nutrients use efficiency (\%) for the treatments in 2004, 2005 and 2006 ( \pm s.e.).

Cuadro 4: Balances de suelo de $\mathrm{N}$ y $\mathrm{P}\left(\mathrm{kg} \mathrm{ha}^{-1} \mathrm{año}^{-1}\right)$ y eficiencia de uso de nutrientes (\%) por tratamiento en 2004, 2005 y 2006 ( \pm e.e.).

\begin{tabular}{|c|c|c|c|c|c|c|}
\hline \multirow[t]{2}{*}{ Treatment } & \multicolumn{2}{|c|}{$\begin{array}{c}63 \text { anim ha- } \mathrm{d}^{-1}, \\
4 \% \text { slope }\end{array}$} & \multicolumn{2}{|c|}{$\begin{array}{c}191 \text { anim ha-1 } \mathrm{d}^{-1}, \\
4 \% \text { slope }\end{array}$} & \multicolumn{2}{|c|}{$\begin{array}{c}63 \text { anim ha- } \mathrm{d}^{-1}, \\
12 \% \text { slope }\end{array}$} \\
\hline & $\mathrm{N}$ & $\mathrm{P}$ & $\mathrm{N}$ & $P$ & $\mathrm{~N}$ & $P$ \\
\hline \multicolumn{7}{|l|}{2004} \\
\hline \multicolumn{7}{|l|}{ Inputs } \\
\hline Rainfall & 3.0 & 0.4 & 3.0 & 0.4 & 3.0 & 0.4 \\
\hline Fertilizer application & 67.5 & 40.0 & 67.5 & 40.0 & 67.5 & 40.0 \\
\hline NBF & 10.1 & - & 26.4 & - & 34.1 & - \\
\hline \multicolumn{7}{|l|}{$\mathrm{N}$ mineralization } \\
\hline Recycling & 52.4 & 21.0 & 56.9 & 23.0 & 40.8 & 14.0 \\
\hline Total inputs & 133.0 & 61.4 & 153.8 & 63.4 & 145.4 & 54.4 \\
\hline \multicolumn{7}{|l|}{ Outputs } \\
\hline Runoff and leaching & 2.2 & 0.001 & 5.2 & 0.002 & 1.1 & 0.007 \\
\hline \multicolumn{7}{|l|}{ Ammonia losses } \\
\hline Total plant uptake & 440.0 & 55.0 & 452.0 & 57.0 & 245.0 & 34.0 \\
\hline Total outputs & 442.2 & 55.0 & 457.2 & 57.0 & 246.1 & 34.0 \\
\hline Soil budget 2004 & -309.2 & +6.4 & -303.4 & +6.4 & -100.7 & +20.4 \\
\hline Efficiency (\%) & 332 & 90 & 297 & 90 & 169 & 62 \\
\hline \multicolumn{7}{|l|}{2005} \\
\hline \multicolumn{7}{|l|}{ Inputs } \\
\hline Rainfall & 2.9 & 0.2 & 2.9 & 0.2 & 2.9 & 0.2 \\
\hline Fertilizer application & 67.5 & 40.0 & 67.5 & 40.0 & 67.5 & 40.0 \\
\hline NBF & 24.7 & - & 61.0 & - & 42.0 & - \\
\hline $\mathrm{N}$ mineralization & 308.0 & - & 308.0 & - & 308.0 & - \\
\hline Recycling & 34.5 & 11.0 & 46.6 & 20.1 & 25.1 & 7.8 \\
\hline Total inputs & 437.6 & 51.3 & 486.0 & 60.4 & 445.5 & 48.0 \\
\hline
\end{tabular}




\begin{tabular}{|c|c|c|c|c|c|c|}
\hline \multicolumn{7}{|c|}{$\begin{array}{l}\text { Continuation Table 4: } \\
\text { Continuación Cuadro 4: }\end{array}$} \\
\hline \multirow[t]{2}{*}{ Treatment } & \multicolumn{2}{|c|}{$\begin{array}{c}63 \text { anim ha- } \mathrm{d}^{-1}, \\
4 \% \text { slope }\end{array}$} & \multicolumn{2}{|c|}{$\begin{array}{c}191 \text { anim ha- } \mathrm{d}^{-1}, \\
4 \% \text { slope }\end{array}$} & \multicolumn{2}{|c|}{$\begin{array}{c}63 \text { anim ha- } \mathrm{d}^{-1}, \\
12 \% \text { slope }\end{array}$} \\
\hline & $\mathrm{N}$ & $\mathrm{P}$ & $\mathrm{N}$ & $\mathrm{P}$ & $\mathrm{N}$ & $P$ \\
\hline \multicolumn{7}{|l|}{ Outputs } \\
\hline Runoff and leaching & 16.0 & 0.01 & 27.0 & 0.01 & 2.0 & 0.02 \\
\hline Ammonia losses & 4.6 & - & 4.6 & - & 4.6 & - \\
\hline Total plant uptake & 366.0 & 54.0 & 475.0 & 68.0 & 381.0 & 50.0 \\
\hline Total outputs & 386.6 & 54.0 & 506.6 & 68.0 & 387.6 & 50.0 \\
\hline Soil budget 2005 & +51.0 & -2.7 & -20.7 & -7.6 & +57.8 & -2.0 \\
\hline Efficiency (\%) & 88 & 105 & 104 & 112 & 87 & 104 \\
\hline \multicolumn{7}{|l|}{2006} \\
\hline \multicolumn{7}{|l|}{ Inputs } \\
\hline Rainfall & 10.3 & 0.9 & 10.3 & 0.9 & 10.3 & 0.9 \\
\hline Fertilizer application & 67.5 & 40.0 & 67.5 & 40.0 & 67.5 & 40.0 \\
\hline NBF & 127.3 & & 136.3 & & 129.1 & \\
\hline $\mathrm{N}$ mineralization & 299 & & 299 & & 299 & \\
\hline Recycling & 72.4 & 25.7 & 51.7 & 14.6 & 47.2 & 17.1 \\
\hline Total inputs & 576.5 & 66.5 & 564.9 & 58.4 & 553.1 & 58.0 \\
\hline \multicolumn{7}{|l|}{ Outputs } \\
\hline Runoff and leaching & 21.3 & 0.01 & 19.4 & 0.01 & 22.2 & 0.02 \\
\hline Ammonia losses & 4,5 & & 4.5 & & 4.5 & \\
\hline Total plant uptake & 529.0 & 69.0 & 573.0 & 69.6 & 485.0 & 61.1 \\
\hline Total outputs & 554.8 & 69.0 & 596.9 & 69.6 & 511.7 & 61.1 \\
\hline Soil budget 2006 & +21.7 & -2.5 & -32.0 & -11.2 & +41.4 & -3.2 \\
\hline Efficiency (\%) & 96 & 104 & 104 & 119 & 92 & 105 \\
\hline
\end{tabular}


Continuation Table 4:

Continuación Cuadro 4:

\begin{tabular}{|c|c|c|c|c|c|c|}
\hline \multirow[t]{2}{*}{ Treatment } & \multicolumn{2}{|c|}{$\begin{array}{c}63 \text { anim ha } \mathrm{h}^{-1} \text {, } \\
4 \% \text { slope }\end{array}$} & \multicolumn{2}{|c|}{$\begin{array}{c}191 \text { anim ha-1 } \mathrm{d}^{-1}, \\
4 \% \text { slope }\end{array}$} & \multicolumn{2}{|c|}{$\begin{array}{c}63 \text { anim ha-1 } \mathrm{d}^{-1}, \\
12 \% \text { slope }\end{array}$} \\
\hline & $\mathrm{N}$ & $P$ & $\mathrm{~N}$ & $P$ & $\mathrm{~N}$ & $\mathrm{P}$ \\
\hline \multicolumn{7}{|l|}{ Overall } \\
\hline \multicolumn{7}{|l|}{ Inputs } \\
\hline Rainfall & $5 \pm 2.6$ & $0.5 \pm 020$ & $5 \pm 2.6$ & $0.5 \pm 0.20$ & $5 \pm 2.6$ & $0.5 \pm 0.20$ \\
\hline Fertilizer application & 67.5 & 40.0 & 67.5 & 40.0 & 67.5 & 40.0 \\
\hline NBF & $54 \pm 36.9$ & & $75 \pm 32.4$ & & $68 \pm 30.4$ & \\
\hline $\mathrm{N}$ mineralization & $304 \pm 4.5$ & & $304 \pm 4.5$ & & $304 \pm 4.5$ & \\
\hline Recycling & $53 \pm 10.9$ & $19 \pm 4.3$ & $52 \pm 3.0$ & $20 \pm 1.6$ & $38 \pm 6.6$ & $13 \pm 2.7$ \\
\hline Total inputs & $483 \mathrm{a}$ & $60 \mathrm{a}$ & $504 a$ & $60 \mathrm{a}$ & $483 \mathrm{a}$ & $54 \mathrm{a}$ \\
\hline \multicolumn{7}{|l|}{ Outputs } \\
\hline Runoff and leaching & 13 & 0.007 & 17 & 0.007 & 8 & 0.02 \\
\hline Ammonia losses & $4,6 \pm 0.05$ & & $4.6 \pm 0.05$ & & $4.6 \pm 0.05$ & \\
\hline Total plant uptake & $445 \pm 47.1$ & $59 \pm 4.8$ & $500 \pm 37.1$ & $65 \pm 4.0$ & $370 \pm 69.5$ & $48 \pm 7.9$ \\
\hline Total outputs & $463 \mathrm{a}$ & $59 \mathrm{a}$ & $522 \mathrm{a}$ & $65 \mathrm{a}$ & $383 \mathrm{a}$ & $48 \mathrm{a}$ \\
\hline Soil budget & $+20 \mathrm{a}$ & $+1 \mathrm{a}$ & $-18 \mathrm{a}$ & $+5 \mathrm{a}$ & $+100 \mathrm{a}$ & $+6 \mathrm{a}$ \\
\hline Efficiency (\%) & $172 \pm 80.0$ & $100 \pm 4.8$ & $168 \pm 64.3$ & $107 \pm 8.7$ & $116 \pm 26.5$ & $90 \pm 14.2$ \\
\hline
\end{tabular}

Different letters in columns indicate significant differences between treatments over the years for $\mathrm{N}$ and $\mathrm{P}$ balances $(\mathrm{P} \leq 0.05)$.

Nitrogen and $\mathrm{P}$ efficiency: relative efficiency of use of $\mathrm{N}$ and $\mathrm{P}$ inputs in components of the system

Amonia losses and $\mathrm{N}$ mineralistaion were measured from 2005 onwards 


\section{Field gate}

The main $\mathrm{N}$ and $\mathrm{P}$ input was inorganic fertiliser. Field $\mathrm{N}$ and $\mathrm{P}$ gate budgets varied between -309 and +58 and between -8 and $+20 \mathrm{~kg}$ of $\mathrm{N}$ and $\mathrm{P} \mathrm{ha}^{-1} \mathrm{yr}^{-1}$, respectively (Table 4), with no difference between treatments $(\mathrm{P}>0.05)$. Overall $\mathrm{N}$ use efficiency varied between 20 and $25 \%$, while overall $\mathrm{P}$ efficiency varied between 9 and $11 \%$.

\section{DISCUSSION}

The increase in the stocking rate and in the field slope did not affect the overall $\mathrm{N}$ and $\mathrm{P}$ soil and gate balances, mainly because the treatments did not affect substantially the exports of DM production and animal product.

\section{Nitrogen and phosphorus budgets}

The large impact of plant uptake on $\mathrm{N}$ and $P$ field gate budgets was clear despite the fact that, from year to year, the amounts of nutrients involved in the budgets were different. Inputs to both the soil and field gate budgets were small compared with other published data in which fertilizer addition and imports in concentrates are the main inputs, with amounts equivalent to over $1,000 \mathrm{~kg} \mathrm{ha}^{-1} \mathrm{yr}^{-1}$ for intensive dairy systems (e.g. Bacon et al. 1990), In the present study, organic matter mineralization was the main $\mathrm{N}$ input for all treatments and $\mathrm{P}$ fertilizer application was the main $\mathrm{P}$ input for all treatments. This situation can be related to the high organic matter content of the soil (>17\%, Table 1$)$. This organic fraction can be transformed to available forms through mineralisation (Whitehead, 2000). The contribution of rainfall to $\mathrm{N}$ and $\mathrm{P}$ inputs was similar to that reported by Oyarzún et al. (1997) for the area (Table 3).

In soil budgets, plant uptake represented between $95 \%$ and $100 \%$ of the total outputs for $\mathrm{N}$ and $100 \%$ of total outputs for $\mathrm{P}$, because $\mathrm{N}$ and $\mathrm{P}$ losses by leaching and runoff were low in relation to other similar cattle production systems. Betteridge et al. (2004) and Haygarth et al. (1998) have reported losses of 30-70 $\mathrm{kg} \mathrm{N} \mathrm{ha}^{-1} \mathrm{yr}^{-1}$ and $5 \mathrm{~kg} \mathrm{P} \mathrm{ha}^{-1} \mathrm{yr}^{-1}$ for British beef production systems, respectively. Our low N losses were probably because the lower stocking rates used and the low $\mathrm{N}$ input in fertilizer. Phosphorus runoff losses were greater in the $12 \%$ slope treatment $(\mathrm{P} \leq 0.05)$, but they were negligible for the soil $\mathrm{P}$ budget. The low estimated values were related to the low runoff production of this volcanic soil, even in the $12 \%$ slope treatment, which is the result of the high infiltration capacity of top soil layer (Alfaro and Salazar, 2007), a typical characteristic of volcanic soils (Dorel et al., 2000).

Overall soil $\mathrm{N}$ budgets were not different between treatments $(\mathrm{P}>0.05)$, probably because the natural variability between years in response to different climate conditions, because $\mathrm{N}$ fertilizer addition was the same in all treatments (Table 1) and because its effect could have been masked by the high soil organic matter content, as described previously for similar soils with inorganic fertilizer addition (Alfaro et al., 2006), so that $\mathrm{N}$ mineralisation could control the $\mathrm{N}$ soil budget over agronomic or animal managements. The tendency to negative budgets with the higher stocking immediate stocking rate was the reflection of a larger plant uptake in this treatment, which resulted in higher nutrient use efficiencies (Table 3). Overall soil $\mathrm{P}$ budgets differed between treatments ( $\mathrm{P} \leq 0.05$; Table 3 ), showing a tendency for $\mathrm{P}$ accumulation in the soil in the $12 \%$ slope treatment $(\mathrm{P} \leq 0.05)$, given by the greater $\mathrm{P}$ input in supplementary feed, as a result of the lower DM yield during winter months in this treatment $(\mathrm{P} \leq 0.05)$.

The direct effect that animals had on $\mathrm{N}$ and $\mathrm{P}$ export was small, as reported by other authors (e.g.Wiiliams, 1998). A greater impact of $\mathrm{N}$ and $\mathrm{P}$ in animal export is expected from more intensive dairy systems as described for New Zealand dairy farms (Haynes And Williams, 1993) and Chilean dairy grazing systems (Nuñez et al., 2008). Higher stocking rates will also favor $\mathrm{N}$ and $\mathrm{P}$ export. Soil $\mathrm{N}$ and $\mathrm{P}$ budgets showed that, in grazed areas when little $\mathrm{N}$ and $\mathrm{P}$ was 
applied as fertilizer, recycling from grazing and soil contribution became important as input and that in grazed areas it is a mechanism by which negative $\mathrm{N}$ and $\mathrm{P}$ balances can be avoided. This could be of high relevance in areas where subsistence agriculture do exist. In practice, whether swards are cut or grazed will depend upon growing conditions during the year and the availability of dry matter for conservation or grazing. The $\mathrm{N}$ and $\mathrm{P}$ budgets presented here are therefore representative of the conditions for the three years of study, but there may be considerable year to year variation as the need to change production from conservation to grazing or vice versa occurs.

Positive gate budgets suggest a nutrient accumulation in the systems, especially with the lower immediate stocking rate and 12 $\%$ field slope, with probable consequences for $\mathrm{N}$ leaching losses and $\mathrm{P}$ over accumulation in the topsoil, as the soils analyses carried out in the present experiment showed (Table 2), in agreement with Jarvis (1993) and Gerber et al. (2002), respectively. This would occur even at low nutrient inputs. This accumulation could reduce the amounts of $\mathrm{N}$ and $\mathrm{P}$ needed as fertilizer in the future and with this, the costs of production, but could also result in increasing $\mathrm{N}$ and $\mathrm{P}$ losses. Results of a parallel experiment had sowed that soil $\mathrm{P}$ sorption capacity would be reached at $30 \mathrm{mg} P$ Olsen $\mathrm{kg}^{-1}$ of soil in the 0-10 cm layer (unpublished data), so that $\mathrm{P}$ accumulation in Andisoils for over this amount could imply a greater risk for $\mathrm{P}$ transfer to surface water and deeper soil layers. This could be especially critical in dairy farms, where the use of animal feed and animal manure (dairy slurry) can lead to a $\mathrm{P}$ over accumulation in the soil, and with that, to greater $\mathrm{P}$ soil budgets.

The $\mathrm{N}$ gate surpluses calculated are low if compared with data of Ryden et al. (1984) who estimated up to $162 \mathrm{~kg} \mathrm{~N} \mathrm{ha}^{-1} \mathrm{yr}^{-1}$ in British grazed pastures, but they are in the range for beef and dairy systems of the area (Dumont and Alfaro, 1998). Phosphorus surpluses estimated were lower than those reported for dairy grazing systems in the area of study, which ranged between 80 and $134 \mathrm{~kg} \mathrm{P} \mathrm{ha}^{-1} \mathrm{yr}^{-1}$ (Dumont and Alfaro, 1998), probably because the lower $P$ input in supplementary feed, in the beef systems.

Even though our results indicate that the risk of nutrients losses from beef grazing systems is low, beef and especially dairy grazing systems of southern Chile should consider best agronomic management practices as a way forward to prevent environmental damage to the area. This is due to the great proportion of surface water bodies (rivers, strems and lakes) located near by grazing paddocks in the area of study. Also, even though $\mathrm{N}$ and $\mathrm{P}$ losses in runoff were low, they were strongly related to inorganic fertiliser application (Alfaro et al., 2008) and to $\mathrm{N}$ and $\mathrm{P}$ concentrations increased on stream waters in the near by area (unpublished data).

On the basis of the present results, the possibilities to improve the efficiency of $\mathrm{N}$ and $\mathrm{P}$ use in such grassland systems are:

- in cut areas, fertilizer application should match $\mathrm{N}$ and $\mathrm{P}$ plant requirements. Heavy applications should be avoided late in summer or at any point during winter, especially prior to heavy rainfall events, when the risk of immediate loss is greater.

- in grazed areas, depending on the stocking rate and the grazing efficiency, the amounts of $\mathrm{N}$ and $\mathrm{P}$ recycled can reach levels equivalent to the amounts applied as mineral fertilizer, especially in low input systems. An efficient grazing system will provide the means of controlling the distribution.

\section{CONCLUSIONS}

The immediate stocking rate and the field slope did not affect $\mathrm{N}$ and $\mathrm{P}$ balances because it did not affect the dry matter yield of the grazing system, as this was the main output of nutrients.

The main $\mathrm{N}$ input in all treatments was the $\mathrm{N}$ mineralization and the main output was plant $\mathrm{N}$ uptake. Livestock production had little effect on $\mathrm{N}$ and $\mathrm{P}$ export, but a 
major influence in the recycling of these elements. The contribution of rainfall to the total $\mathrm{N}$ and $\mathrm{P}$ inputs to the systems was small.

Because of the high number of water bodies present in southern Chile, beef and especially dairy grazing systems, should consider best management practices as a way forward to prevent environmental damage to the area. The use of soil and field gate budgets provided an effective tool to look at the integrated effects of management on $\mathrm{N}$ and $\mathrm{P}$ status in these systems.

\section{ACKNOWLEDGEMENTS}

Thanks to FONDECYT 1040104 and 7050219. Also, thanks to Rodolfo Saldaña for his help in laboratory matters.

\section{REFERENCES}

Alfaro, M., Salazar, F. 2005. Ganadería y contaminación difusa, implicancias para el sur de Chile. Chilean Journal of Agricultural Research 65, 330-340.

Alfaro, M., Salazar, F.J., Endress, D., Dumont, J.C., Valdebenito, A. 2006. Nitrogen leaching losses on a volcanic ash soil as affected by the source of fertiliser. Journal of Soil Science and Plant Nutrition 6, 54-63.

Alfaro, M., Salazar, F. 2007. Phosphorus losses in surface runoff on a volcanic soil. Soil Use and Management 23, 323327.

Alfaro, M., Salazar, F., Iraira, S., Teuber, N., Villarroel, D., Ramírez, L. 2008. Nitrogen, phosphorus and potassium losses in a grazing system with different stocking rates in a volcanic soil. Chilean Journal of Agricultural Research 68, 146-155.
Anrique, R. 1999. Caracterización del Chile lechero. In: Producción Animal (ed L. Latrille), Universidad Austral de Chile Valdivia Chile, pp. 140-157.

Association of Official Agricultural Chemist (AOAC). 1970. Official methods. William Horwist Washington, DC, USA.

Betteridge, K., Ledgard, S.F., Lambert, M.G., Thorrold, B., Costall, D.A., Theobald, C.J., Hoogendoorn, C.J., Park, Z.A. 2004. Reduced nitrate leaching from livestock-based system in New Zealand's largest lake catchment. Proceeding of the European Conference for Precision Livestock Farming.

CIREN, 2003. Descripciones de suelos, materiales y símbolos, estudio agrológico X Región Vol. II, Centro de Información de Recursos Naturales Santiago Chile.

Clesceri, L.S., Greenbarg, A.E., Eaton, A.D. 1998. Standard methods for the examination of water and waste water. American Public Health Association, American Water Works Association, Water Environment Federation. United Book Press Inc. Baltimore USA.

CONAMA, 1998. Política ambiental de la Región de los Lagos. Comisión Nacional del Medio Ambiente. Available at http://www.conama.cl/portal/1255/arti cle26198.html. Last access 21st of April 2003.

Dorel, M., Roger-Estrade, J., Manichon, H., Delvaux, B. 2000. Porosity and soil water properties of Caribbean volcanic ash soils. Soil Use and Management 16, 133-140.

Dumont, J.C., Alfaro, M.A. 1998. Balance de nutrientes en sistemas lecheros de Osorno con distintas intensidades de producción. p. 89. In IV Congreso Internacional en Gestión en Recursos Naturales, Sustentabilidad del Siglo XXI, Puyehue, Chile. 23-27 de nov. Soc. Chilena de Biología, Santiago Chile. 
Gerber, P., Franceschini, G., Menzi, H. 2002. Livestock density and nutrient balances across Europe. FAO. Livestock Environment \& Development Initiative ( LE A D). A vailable a t http://lead.virtualcenter.org/en/frame.h tm. Accessed 27th February 2003

Hatch, D.J., Jarvis, S.C., Phillips, L. 1990. Field measurements of nitrogen mineralisation using soil core incubation and acetylene inghibition of nitrification. Plant and Soil 124, 97-107.

Haygarth, P.M., Chapman, P.J., Jarvis, S.C., Smith, R.V. 1998. Phosphorus budgets for two contrasting grassland farming systems in the UK. Soil Use and Management 14, 160-167.

Haynes, R.J., P.H. Williams. 1993. Nutrient cycling and soil fertility in the grazed pasture ecosystem. Advances in Agronomy 49, 119-199.

INE, 2007. Informe estadísticas agropecuarias para el periodo 2001-2006 y primer semestre 2007. Accessed in december 2007. Available from: <http://www.ine.cl/canales/chile_estad istico/estadisticas_agropecuarias/pdf/p ecuarioprimersemestre2007_2.pdf.

Jarvis, S.C. 1993. Nitrogen cycling and losses from dairy farms. Soil Use and Management 9, 99-105.

Jarvis, S.C., Oenema, O. 2000. Measuring and monitoring nitrogen and phosphorus flows and losses in grassland systems. In: Field and Laboratory Methods for Grassland and Animal Production Research (eds. L't. Mannetje \& R.M. Jones), CAB International Cambridge UK, pp. 305-325.

Ledgard, S.F., Penno, J.W., Sprosen, M.S. 1999. Nitrogen inputs and losses from clover/grass pastures grazed by dairy cows, as affected by nitrogen fertilizer application. Journal of Agricultural Science (Cambridge) 132, 215-225.
Lord, E.I., Shepherd, M.A. 1993. Development in the use of porous ceramic cups for measuring nitrate leaching. Journal of Soil Science 44, 435-449.

Mora, M., Alfaro, M., Jarvis, S.C., Demanet, R., Cartes, P. 2006. Soil aluminium availability in andisols of southern Chile and its effect on forage production and animal metabolism. Soil Use and Management 22, 95-101.

Misselbrook, T.H., Van Der Weerden, T.J., Pain, B.F., Jarvis, S.C., Chambers, B.J., Smith, K.A., Phillips, V.R., Demmers, T.G.M. 2000. Ammonia emission factors for UK agriculture. Atmosphere and Environment 34, 871-880.

Mulvaney, R.L. 1996. Nitrogen - Inorganic forms. In: Sparks D.L. et al. (eds) Methods of soil analysis: chemical methods. Soil Science Society of America, Book Series No. 5:1123-1184 Madison, Wisconsin.

NRC, National Research Council. 1996. Nutrient requirements of beef cattle. 7 th edition. National Academic Press, Washington, USA. 242 p.

Núñez, P., Demanet, R., Alfaro, M., Mora, M.L. 2009. Nitrogen soil budgets in Chilean dairy grazing systems. Chilean Journal of Agricultural Research, accepted.

Oyarzun, C.E., Campos, H., Huber, A. 1997. Exportación de nutrientes en microcuencas con distinto uso del suelo en el sur de Chile. Revista Chilena Historia Natural 70, 507-519.

Robarge, W.P., Edwards, A., Johnson, B. 1983. Water and waste water analysis for nitrate via nitration of salicylic acid. Communication in Soil Science and Plant Analysis 14,1207-1215. 
54 Nutrients balances in beef cattle and their impact on the environment, Alfaro et al.

Ryden, J.C., Ball, P.R., Garwood, E.A. 1984. Nitrate leaching from grassland. Nature 311: 50-53.

Sadzawka, A. 1990. Métodos de análisis de suelos. INIA La Platina No 16 Instituto de Investigaciones Agropecuarias Ministerio de Agricultura Santiago Chile.

Sadzawka, A., Grez, R., Carrasco, M., Mora, M. 2004. Métodos de análisis de tejidos vegetales. Comisión de Normalización y Acreditación, Sociedad Chilena de la Ciencia del Suelo, Chile. 53p.
Van Noordwijk, M. 1999. Nutrient cycling in ecosystems versus nutrient budgets of agricultural systems. In: Nutrient desequilibria in agroecosystems, concepts and case studies, eds EMA Smaling O Oenema \& LO Fresco, CAB International Cambridge pp 1-26.

Whitehead, D.C. 2000. Nutrient elements in grassland. Soil- plant- animal relationships. CABI Publishing, Wallingford, UK.

Williams, P.H. 1988. The fate of potassium in grazed dairy pastures. PhD Thesis Massey University. 